\title{
'n Eksegetiese ondersoek na die leierseienskappe wat Paulus in Filippense 3:1-16 toon
}

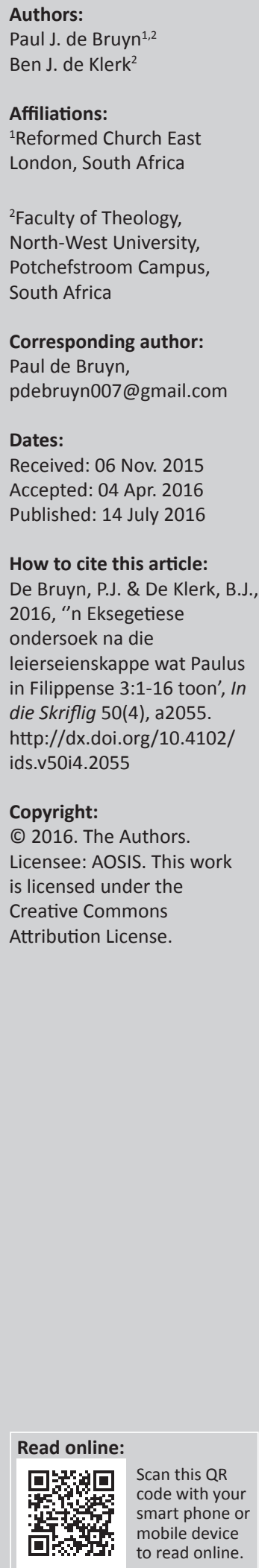

This article is the result of a thesis, submitted in 2015, with the following title: A PastoralTheological Study of Effective and Responsible Leadership of the Afrikaans-Speaking Minister in the Congregation's Call. The problem investigated regards the fact that leadership in the church is not defined properly and, as a result, no clear guidance exists for ministers on what is expected of them as leaders. This article focuses on Paul as leader of the New Testament church. An exegetical investigation of Philippians 3:1-16 will be conducted to determine what this passage reveals about his strengths as a leader.

\section{Inleiding en probleemstelling}

Ons leef in 'n tyd waarin lidmate hoë verwagtings van kerkleiers het. Daar word van hulle verwag om goeie predikers te moet wees, om 'n morele lewe te lei, om hulle gemeentes te laat groei en om 'n duidelike missie en visie te hê, om maar enkele verwagtings te noem. Daar is 'n gesegde wat lui: The fate of the nation, humanly speaking, rests in the hands of the church, and the fate of the church rests in the hands of its leaders (Rardin 1998:1). Die leiers in die kerk bepaal in 'n groot mate die voortbestaan, geestelike welsyn en morele waardes van die samelewing. Die vraag is watter leierseienskappe die predikant moet hê om sy verantwoordelikheid na te kom. Die doel van hierdie artikel is om ondersoek in te stel na die leierseienskappe van Paulus soos blyk uit sy skrywe aan die gemeente van Filippi. Deur die eksegese van Filippense 3:1-16 ${ }^{1}$ sal probeer word om vas te stel wat Paulus self as belangrike leierseienskappe in sy lewe beskou het en hoe hy as leier ontwikkel het. Die metode wat gevolg word, is 'n grammaties-historiese eksegese (vgl. De Klerk \& Janse van Rensburg 2005; Lotter 1993:11).

\section{'n Eksegetiese ondersoek van 3:1-16}

Die klem val op die volgende aspekte:

- Die leierseienskap wat Paulus in sy reaksie teenoor die dwaalleraars toon.

- Paulus se begronding vir sy status as leier voor sy bekering.

- Paulus se doelwitte as leier ná sy bekering.

- Paulus se inspanning as leier van die kerk ná sy bekering.

\section{Die leierseienskap wat Paulus in sy reaksie teenoor die dwaalleraars toon (Fil 3:1-2)}

Filippense 2 sluit af met Paulus wat vir Timoteus en Epafroditos loof vir die onbaatsugtige werk wat hulle in diens van Christus gedoen het. Albei hierdie mans het ander mense se belange bo hulle eie gestel en sodoende het hulle 'n voorbeeld van ware Christus-diens geword (Melick 1991). ${ }^{2}$ Met hierdie onbaatsugtige diens in gedagte begin Paulus in Filippense 3 deur te konsentreer op mense wat presies die teenoorgestelde gesindheid gehad het, naamlik die dwaalleraars. Paulus noem hulle 'honde' (Kvvós) omdat hulle deur hulle dade mense uitmekaar skeur. Calvyn en Pringle (2010) verklaar die gebruik van hierdie beeld soos volg: ... for the sake of filling their belly, they assailed true doctrine with their impure barking. Accordingly, it is as though he had said,-impure or profane persons ...

Paulus het die wysheid gehad om deur hierdie dwaalleraars te sien. Hulle is onrein omdat hulle dink dat hulle God se werk doen, maar intussen maak hulle staat op uiterlike dinge soos die besnydenis (Van Zyl 1993). Hierdie dwaalleraars vestig, volgens Müller (1992), hulle hoop op verlossing deur die besnydenis en deeglike wetsonderhouding in plaas van die heilswerk van Christus. Carson et al. (1994) vat dit raak saam wanneer hulle sê dat dit vir hierdie dwaalleraars 1.Verdere verwysings na die boek Filippense sal slegs met hoofstukke en verse aangedui word

2.Alle bronverwysings waar nie bladsynommers voorkom nie, is verkry van die Logos Bible Software, 'n sagtewareprogram waarby geen bladsynommers aangedui word nie. 
waarna Paulus verwys eerder daaroor gegaan het om van die heidene Jode te maak in plaas van dissipels van Christus.

Paulus wou seker maak dat die gelowiges in Filippi nie deur die toedoen van hierdie dwaalleraars in 'n wettiese benadering tot godsdiens verval nie, maar dat hulle self ook die onderskeidingsvermoë sal hê om deur die dwaalleraars te sien. Daarom het hy hom herhaaldelik daaroor uitgespreek (vgl. 3:1). Vosloo en Van Rensburg (1999) maak die volgende opmerking:

... dit [kan] so maklik gebeur dat mens aan hierdie uiterlike dinge te veel waardeheg, datjy jou sekerheid, jou geloofsekerheid, aan uiterlike, sigbare dinge koppel. Jou grootste vreugde ervaar jy dan wanneer hierdie uiterlike, sigbare dinge nie verander nie. Maar ook die omgekeerde: jou grootste ontsteltenis ervaar jy wanneer sulke dinge wel verander.

Dit is daarom belangrik dat die gelowige nie sy geloofsekerheid in kulturele gebruike moet soek nie maar in Christus. Wiersbe (1992) ondersteun hierdie stelling: Paul was religious before he was saved, but his religion could not save him. He had to lose his religion in order to find eternal life! In ware godsdiens plaas die mens nie sy vertroue op uiterlike dinge nie, maar alleen op Jesus die Christus (1 Kor 1:31; Jer 9:23-24). In Hom ontdek die gelowige wat ware blydskap is.

Verder sê Vosloo en Van Rensburg (1993) dat dinge wat 'n mens bly en hartseer maak, boekdele spreek oor wat werklik vir jou belangrik is. Dit gebeur so maklik dat gelowiges se gemoedere deur hulle omstandighede beïnvloed word. Paulus wys egter dat hy die nodige onderskeidingsvermoë gehad het om te besef dat ware blydskap alleen in Christus te vinde is (vgl. $1: 4 ; 18-20 ; 2: 17 ; 3: 1 ; 4: 4)$. Christus moet die gelowige se grootste skat wees (vgl. Matt 6:21) en daarom is Christus die bron van alle ware blydskap (Van Zyl 1993). Dit is hierdie blydskap in Christus wat niks of niemand van die gelowige kan wegneem nie (Joh 16:22). Daarmee stel Paulus dit van die begin van Filippense (vs. 1:18, 2:17; 3:1) af baie duidelik dat die spil van ware blydskap in Christus is en nie in uiterlike dinge nie (vgl. 1:3).

Uit die beredenering hierbo is dit duidelik dat Paulus in sy optrede en leer onderskeidingsvermoë getoon het: Paulus het ingesien dat wettiese godsdiens ' $n$ valse godsdiens is en daarom het hy die gelowiges teen hierdie dwaalleer gewaarsku. Die ware godsdiens is geestelik omdat dit uit 'n opregte hart voortvloei (Joh 7:38), 'n hart wat deur die Heilige Gees vernuwe is.

Verder het Paulus die gelowiges geleer dat hulle blydskap in Christus se werk moet setel en nie in hulle eie onvolmaakte arbeid nie. Sodoende sal hulle geluk nie deur onsekere omstandighede beïnvloed word nie.

\section{Paulus se begronding vir sy status as leier voor sy bekering (3:3-6)}

MacArthur (2001) meen dat Paulus se mededeling oor sy lewe voor sy bekering (3:4-11) bedoel is om aan te dui hoe drastiese sy lewe verander het ná sy persoonlike ontmoeting met Jesus Christus, (vgl. Hand 9:1-9). Dit was 'n ontmoeting wat hom van die mees gevreesde vervolger van die kerk (Hand 9:13-14) in die mees geliefde apostel laat verander het.

Die biografiese besonderhede wat Paulus in 3:5-6 gee, kan in twee kategorieë verdeel word, naamlik die bates wat hy oorgeërf het (die eerste drie; vgl. onderstaande opskrif 'Oorgeërfde bates wat Paulus se status as leier bepaal het') en die dinge waarvoor hy gewerk het (die laaste vier; vgl. opskrif 'Bates waarvoor Paulus hard gewerk het as die grond vir sy status') (MacArthur 2001; Melick 1991). Hierdie bates het Paulus se identiteit as leier voor sy bekering bepaal.

\section{Oorgeërfde bates wat Paulus se status as leier bepaal het (3:5a)}

Die eerste bate wat Paulus noem, is sy besnydenis op die agste dag. Die Mosaïese wet het voorgeskryf dat Joodse seuntjies op die agste dag na hulle geboorte besny moes word. Hawthorne (2004) beweer dat dit vir 'n Jood die grootste trots was om te kon sê dat hy die besnydenis streng volgens die voorskrifte van die Mosaïese wet ondergaan het (vgl. Lev 12:3).

Verder was Paulus se geboorte as Israeliet, volgens MacArthur (2001), belangrik omdat dit daarop dui dat hy deel was van God se uitverkore volk waarvan die Here self gesê het: 'Ek het net vir julle uitgekies uit al die volke van die aarde ...' (Am 3:2). Dit het meegebring dat Paulus daarop kon aanspraak maak dat hy net soos enige ander Jood geregtig was op al die voordele van die volk van God.

Laastens blyk dit uit verskillende kommentare (Hawthorne 2004; MacArthur 2001; Robertson 1933; Vincent 1887) dat daar tot 10 verskillende redes is hoekom Paulus daarop sou kon roem dat hy uit die stam van Benjamin gebore is. Enkele van hierdie redes is dat, van al die kinders van Jakob, dit net Benjamin was wat in die beloofde land gebore is. Baie mense met hoë aansien in die volk se geskiedenis is uit die stam gebore, byvoorbeeld Saul, die eerste koning van Israel (1 Sam 9:1-2), en Mordegai, wat daartoe bygedra het dat Israel van totale uitwissing gered is (vgl. die boek Ester). Boonop was die heilige stad, Jerusalem, en die tempel geleë binne die grense wat aan Benjamin toegeken is.

Dit is dus duidelik dat Paulus sy waardigheid en status as leier van God se volk in sy oorgeërfde bates sou kon soek.

\section{Bates waarvoor Paulus hard gewerk het as die grond vir sy status (3:5b-6)}

Dat Paulus noem dat hy 'n egte Hebreër is. Dit dui moontlik daarop dat hy die volkstaal kon praat, naamlik Hebreeus (Hand 22:2). Hy is dus opgevoed in 'n eg Joodse leefwyse (Hawthorne 2004) wat dikwels groot opoffering en harde werk beteken het.

Verder was hy in wetsopvatting 'n Fariseër. Die Fariseërs was bekend vir hulle liefde vir die wet en die streng interpretasie en toepassing daarvan (Melick 1991). MacArthur (2001) 
skryf: To be a Pharisee was to be a member of an elite, influential, and highly respected group of men who fastidiously lived to know, interpret, guard, and obey the Law. Hierdie wet, wat hulle so getrou nagekom het, is deur die rabbi's van die tyd geskryf en saamgestel.

Vervolgens noem Paulus dat hy 'n vervolger van die kerk was. Daardeur wil Paulus wys dat hy sy liefde vir sy godsdiens en sy volk bewys het deur die kerk te vervolg.

Laastens noem Paulus dat hy onberispelik was in die onderhouding van die wet van Moses om vryspraak te verkry. Hier gaan dit daaroor dat Paulus nooit daarvan beskuldig kon word dat hy enige van die wette wat deur die rabbi's gemaak is, oortree het nie (Robertson 1933). In die publiek se oë was hy sonder blaam (Melick 1991).

Dit is belangrik om te sien dat die dinge wat Paulus hier noem nie op sigself verkeerd was nie. Baie van hierdie sake was immers voorskrifte wat in die wet voorgeskryf is (bv. die besnydenis en onderhouding van die wet). Die probleem was egter dat die streng navolging van hierdie sake die fokus na homself geskuif het. Deur hierdie sake volkome na te kom was vir hom 'n poging om sy eie verlossing te bewerk.

Paulus noem hierdie voortreflikhede omdat sy status as leier van die volk van God gebaseer sou kon word op die ywer en opofferings wat hy as leier gemaak het. Nadat hy Christus egter ontmoet het, verander sy selfbeskouing (vgl. Fil 3:12; Rom 7:7-12). Die gelowige se kliphart word verwyder (Eseg 11:19; Rom 2:29) sodat hy kan insien dat dit vir God oor meer as die nakoming van blote uiterlike reëls en voorskrifte gaan.

$\mathrm{Al}$ hierdie dinge waarvoor Paulus voor sy bekering so hard gewerk het, het daartoe gelei dat hy neergekyk het op mense wat nie dieselfde bates as hy gehad het nie of wat hulle godsdiens nie so goed soos hy beoefen het nie. Calvyn en Pringle (2010) wys daarop dat ' $n$ persoon wat hoogmoedig is, heel waarskynlik geen intieme verhouding met Christus het nie. Hulle sê:

Hence, where we see a false estimate of one's own excellence, where we see arrogance, where we see pride, there let us be assured that Christ is not known. On the other hand, so soon as Christ shines forth, all those things that formerly dazzled our eyes with a false splendour instantly vanish, or at least are disesteemed.

Al waarop 'n gelowige wil en kan roem, is op Christus, wat vir hom die vryspraak verwerf het (vgl. Rom 3:27; 1 Kor 1:29-31).

In hierdie argument kan veral twee afleidings gemaak word oor Paulus se leierskap voor sy bekering. Dit is eienskappe wat nié by 'n gelowige leier wat op Christus alleen roem, gevind behoort te word nie:

- 'n Leier wat nie op Christus alleen roem nie, maak staat of roem op prestasies wat hy self in sy lewe vermag het. Omdat Paulus voor sy bekering nie die nodige geestelike onderskeidingsvermoë gehad het om te besef dat hy op niks anders as op Christus kon roem nie, het hy gesteun op die prestasies wat hy in eie krag in sy lewe vermag het.

- Die status wat Paulus as leier voor sy bekering gehad het, is nie deur nederige verantwoordelikheid gekenmerk nie omdat dit gegrond was op sake wat hy self vermag het. Sodra 'n leier fokus op prestasies wat hy self vermag het en sy status daarin soek, sal hoogmoed intree. Slegs 'n leier wat weet wat Christus vir hom gedoen het, sal nooit hoogmoedig kan wees nie.

\section{Paulus se doelwitte as leier ná sy bekering (3:7-11)}

Waar Paulus voor sy bekering begeer het om in alles wat hy gedoen het uit te blink, is sy grootste begeerte ná sy bekering 'n intieme verhouding met Christus (vgl. 3:10). Paulus gee nie net alles prys wat vroeër vir hom waardevol was nie (vgl. 3:8), maar hy beskou dit as verwerplik. Volgens Calvyn en Pringle (2010) beskryf die woorde in 3:10 die houding van seemanne wat in die middel van 'n storm besluit om alles oorboord te gooi om te verhoed dat hulle skipbreuk ly. Die 'goeie lewe' wat Paulus as Fariseër gehad het, beskou hy nou as verwerplik in die lig van sy lewe in Christus. Soos die seeman besef dat die bagasie ' $n$ bedreiging vir sy lewe inhou en dat hy dit daarom eerder weggooi, so besef Paulus nou dat die dinge wat hy vroeër as 'n bate beskou het, 'n gevaar vir sy lewe is (Müller 1992).

In die lewe van die gelowige mag niks so belangrik soos Christus wees nie. Daardie dinge wat belangriker as Christus word, moet oorboord gegooi word. Paulus het dit prakties gedoen toe hy ter wille van Christus sekerlik ook familiebande, vriendskap en sy eer as Fariseër prysgegee het (Vosloo \& Van Rensburg 1993). Terselfdertyd skryf Wiersbe (1996) dat Paulus se woorde nie beteken dat hy niks meer daarmee te doen wou hê nie:

Becoming a Christian did not make him less a Jew. In fact, it made him a completed Jew, a true child of Abraham both spiritually and physically (Gal. 3:6-9). Nor did he lower his standards of morality because he saw the shallowness of pharisaical religion. He accepted the higher standard of living conformity to Jesus Christ (Rom. 12:1-2). When a person becomes a Christian, God takes away the bad, but He also takes the good and makes it better.

Alles wat die gelowige nodig het, ontvang hy in Christus. Om hierdie rede het Paulus alles wat vroeër vir hom 'n bate was, opgegee sodat hy dít kon kry wat werklik waarde gehad het, naamlik Christus self en nie net bloot die guns van Christus nie (Hawthorne 2004).

Verder beklemtoon Paulus in 3:9 die innige geloofsverbintenis wat daar tussen die gelowige en Christus is (Müller 1992). In hierdie eenheid kry die gelowige deel aan al die weldade van Christus en daarom kan elke gelowige saam met Paulus in sy brief aan die Galasiërs sê:

... en nou is dit nie meer ek wat lewe nie, maar Christus wat in my lewe. Die lewe wat ek nou nog hier lewe, leef ek in die geloof in die Seun van God wat sy liefde vir my bewys het deur sy lewe vir my af te lê. (2:20) 
In aansluiting hierby skryf Melick (1991) dat om 'n Christen te wees, beteken om eerder met God se regverdigheid as jou eie beklee te wees. Dit herinner aan die gelykenis wat Jesus van die bruilof vertel het (Matt 22). Die koning het aan elkeen van die gaste 'n kleed gegee om aan te trek, maar die een wat nie daardie kleed wou aantrek nie, is in die diepste duisternis uitgegooi.

Calvyn en Pringle (2010) wys daarop dat Paulus hier (vgl. 3:9) oor twee tipes vryspraak praat. Die eerste is afhanklik van die mens omdat hy dit ontvang op grond daarvan dat hy die wet onderhou. Die ander vryspraak kom van God. Hy stuur Christus om die wet in die mens se plek te onderhou en so word Hy die kleed (vgl. Rom 13:14, Ou Afrikaanse vertaling - OAV) wat die mens moet aantrek om vryspraak te verkry. Elke gelowige kan nou daardie kleed aantrek deur geloof in Christus. Hierdie twee tipes vryspraak staan lynreg teenoor mekaar.

Paulus ken al twee hierdie weë omdat hy ook eers deur wetsonderhouding probeer het om sy vryspraak te verkry. Hieroor sê MacArthur (2001) dat Paulus, al het hy sy uiterste bes probeer, steeds heeltemal tekortgeskiet het (Rom 3:23). Die las om deur eie dade vryspraak te ontvang, is net te groot vir die mens om te dra (vgl. Hand 15:10). Buitendien lei dit altyd tot hoogmoed. Hawthorne (2004) verduidelik hoe dit gebeur: The trouble with a righteousness based on what a person can do is that it is always self-righteousness (cf. Rom 10:1-3), providing a basis for self-boasting.

Vosloo en Van Rensburg (1999) pas dit prakties toe deur te sê dat wanneer 'n persoon voor die regterstoel van God staan en hy hom op die eerste tipe vryspraak beroep, hy al die prysenswaardige dade in sy lewe sal moet opnoem, maar nogtans besef dat selfs sy beste dade soos vuil klere voor die Here is (vgl. Jes 64:6). Indien 'n persoon egter voor die regterstoel van God staan en hom op die tweede tipe vryspraak beroep, hoef hy nie op te noem wat hy gedoen het nie. Hy hoef slegs te noem wat Christus vir hom gedoen het. Christus het die volle prys vir die gelowige se sonde betaal. Daarom sê Paulus: 'Christus was sonder sonde, maar God het Hom in ons plek as sondaar behandel sodat ons, deur ons eenheid met Christus, deur God vrygespreek kan wees'. (2 Kor 5:21)

Daarom noem Paulus na sy bekering veel eerder die voortreflikheid wat hy as wins in Christus ontvang het. Hierdie voortreflikheid wat hy in Christus ontvang is nou sy begeerte en in hierdie begeerte kan vyf wense of doelwitte onderskei word.

\section{Eerste wens of doelwit: Kennis (3:8)}

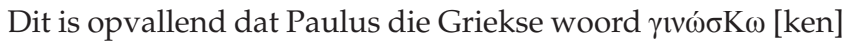
gebruik. Volgens Keener (1993) is die kennis waarna hier verwys word, meer as 'n blote intellektuele bewustheid. Hierdie woord beskryf die diep en innige liefdesverhouding tussen 'n man en vrou wat met mekaar gemeenskap het (MacArthur 2006). Hulle ken mekaar innig, diep. Hierdie kennis is daarom nie bloot net om te weet wie Jesus is nie, maar dit gaan oor ' $n$ intieme, persoonlike verhouding met Hom. Jesus waarsku sy dissipels in Matteus 7 teen 'n verkeerde opvatting van die kennis:

Baie sal daardie dag vir My sê: 'Here, Here, het ons dan nie in u Naam gepreek nie, deur u Naam bose geeste uitgedryf en deur u Naam baie wonders gedoen nie?' Dan sal Ek openlik vir hulle sê: 'Ek het julle nooit geken nie. Gaan weg van My af, julle wat die wet van God oortree. (v. 22-23)

Onder kennis verstaan Paulus die intieme band wat deur die eiesoortige kennis van Christus meegebring word en waarna hy as leier streef.

\section{Tweede wens of doelwit: Vryspraak in Christus (3:9)}

Die persoon vir wie hierdie wêreld sy wins is, sal alles in sy vermoë doen om te bewys dat hy 'n beloning verdien. Voor Paulus se bekering het hy presies op hierdie manier opgetree en daarom het hy selfs so ver gegaan om die kerk van Christus te vervolg. Ná sy bekering het hy besef dat daar niks is wat hy kan doen om vrygespreek te word nie omdat hy 'n gebroke mens is. Christus het alles gedoen en deur 'n vaste geloof in Hom kry ook Paulus deel aan die heerlikheid van Christus. Die klem in Paulus se lewe as leier verskuif dus van die persoon wat die eerste probeer wees na Christus wat alleen die eerste is. Hy alleen is volmaak. Hy was volkome gehoorsaam aan die wil van God en deur die geloof in Hom word ook Paulus vrygespreek.

\section{Derde wens of doelwit: Krag (3:10)}

Paulus sê in 3:10 dat hy alles sal prysgee om die krag van Jesus Christus se opstanding te mag ondervind. In geeneen van Christus se werke op aarde is daar soveel krag geopenbaar as in sy opstanding nie. Dat Hy uit die dood opgestaan het, het getoon dat Hy mag oor die fisiese sowel as die geestelike wêreld het. Dit is hierdie selfde opstandingskrag wat Paulus gered het. Die dag toe hy sy sonde kon afsterf en kon opstaan in 'n nuwe lewe wat hy aan Jesus Christus toegewy het, het hy hierdie krag ondervind. Die krag van Christus het meegebring dat Paulus as leier van die kerk versoekings kon oorkom, Christus kon dien, kon opkom vir sy geloof ten koste van homself en eendag ook uit die dood sal opstaan om die sonde finaal te oorwin (vgl. Ef 1:18-20). Dit is hierdie krag van Christus wat Paulus in sy lewe as leier sigbaar wil laat word.

\section{Vierde wens of doelwit: Gemeenskap aan sy lyding (3:10)}

Dat Paulus aan Christus se lyding deel wou hê, sal vir die wêreld onverklaarbaar wees, maar vir elke gelowige hou lyding groot troos in. Omdat Paulus Christus geken het, het hy die diepste, intiemste gemeenskap met Christus in sy lyding ervaar (MacArthur 2001). Die rede daarvoor is dat Paulus in Christus die genadige en barmhartige Hoëpriester gevind het. Hebreërs 4:15-16 lui soos volg:

Die Hoëpriester wat ons het, is nie Een wat geen medelye met ons swakhede kan hê nie; Hy was immers in elke opsig net soos ons aan versoeking onderwerp, maar Hy het nie gesondig nie. 
Kom ons gaan dan met vrymoedigheid na die genadetroon, sodat ons barmhartigheid en genade ontvang en so op die regte tyd gered kan word.

Die wonderlike wat Paulus in sy lyding kon ervaar, was dat hy ' $n$ metgesel gehad het - iemand wat nie net deur soortgelyke lyding gegaan het nie, maar baie erger. Boonop het Christus alleen deur die angs van Godverlatenheid gegaan sodat Paulus nooit in sy lyding sonder Christus sou wees nie. Selfs in sy diepste lyding was Christus steeds by hom en daarom kon hy as gelowige leier 'n diep gemeenskap met Christus in sy lyding hê.

\section{Vyfde wens of doelwit: Ewige heerlikheid (3:11)}

In 3:11 praat Paulus van daardie oomblik wat Jesus Christus op die wolke sal kom en die gelowiges uit die dood sal opstaan. Dit is die dag wanneer die gelowige 'n verheerlikte liggaam sal kry. In 3:21 beskryf hy daardie moment soos volg: 'Deur die krag waarmee Hy alles aan Homself onderwerp, sal Hy ons nederige liggame verander om soos sy verheerlikte liggaam te wees'. Paulus het daarom vanuit die hoop geleef dat hy saam met Christus ook eendag verheerlik sal word.

Uit Paulus se doelwitte as leier word die volgende duidelik oor sy leierskap:

- Paulus het alles wat vir hom vroeër 'n bate was, opgegee sodat hy dit kon kry wat werklik waarde het, naamlik 'n lewe in Christus. Hy aanvaar dus self die verantwoordelikheid om hom volkome aan Christus toe te wy deur Hom as sy hoogste begeerte na te jaag. Die tweede (vryspraak) en vyfde (ewige heerlikheid) wens of doelwit sluit hierby aan.

- Paulus het ook prakties gewys dat hy sy lewe onder Christus se heerskappy stel wanneer hy ter wille van Christus alles wat vir hom vroeër waardevol was, verwerp het. Hy kon dit doen omdat hy nie meer op homself nie, maar op Christus vertrou het. Dit hang saam met die derde wens of doelwit (krag), om Christus in sy lewe sigbaar te laat word. As Paulus hom aan Christus onderwerp, doen hy dit met die wete dat Christus die krag van die opstanding in hom het. Paulus hoef nie meer op sy eie beperkte krag staat te maak nie, maar hy kan vertrou dat die groot krag van Christus in hom sigbaar sal word.

- Uit die laaste doelwit is dit duidelik dat Paulus die wysheid gehad het om te besef dat die begeerte om in mense se oë belangrik te wees nie ewigheidswaarde het nie. Die eerste wens of doelwit (kennis) sluit hierby aan omdat hy die geestelike onderskeidingsvermoë ontvang het om sy fokus te verskuif deur veel eerder na 'n innige verhouding met Christus, sy Verlosser, te soek, as die erkenning van mense. Ook die vierde wens of doelwit (gemeenskap aan Christus se lyding) hou verband hiermee omdat Paulus iets begeer het wat vir die wêreld onverklaarbaar is. Hy het besef dat hy selfs in sy lyding 'n metgesel het - Een wat deur baie groter lyding as hy vir hom gegaan het.

\section{Paulus se inspanning as leier van die kerk ná sy bekering (3:12-16)}

Dit is opvallend dat Paulus dit hier baie duidelik stel dat die lewe van 'n gelowige nie maklik is nie en gereeld deur inspanning gekenmerk word. Hawthorne (2004) meen dat die woorde 'ek span my in' (3:12) herinner aan 'n wedloop waarin die atleet hom na die wenstreep uitstrek om die oorwinning te behaal. Net so strek Paulus hom uit sodat sy kennis van Christus steeds sal toeneem totdat hy aan die einde die oorwinnaarskroon sal ontvang (vgl. 2 Tim 4:8). Hierdie inspanning word verder beklemtoon wanneer

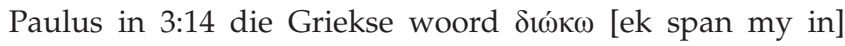
gebruik. Hierdie uitdrukking is dikwels gebruik om 'n jagter te beskryf wat sy prooi bekruip (Wiersbe 1996). Louw en Nida (1996) definieer die woord soos volg: To follow with haste, and presumably with intensity of effort, in order to catch up with, for friendly or hostile purpose. Paulus gebruik dieselfde woord in 3:6 om te verduidelik hoe hy die kerk vervolg het. In stede daarvan om die kerk te vervolg, span Paulus nou al sy krag in om Christus in sy volheid te leer ken.

Die rede waarom Paulus hom met soveel ywer inspan om Christus te leer ken, is dat Christus hom reeds syne gemaak het (vgl. 3:12). Henry (1994) verduidelik dat die gelowige se blydskap in verlossing juis daarin lê dat Christus die eerste tree tot versoening gegee het. Paulus stel dit eksplisiet: 'Maar God bewys sy liefde vir ons juis hierin dat Christus vir ons gesterf het toe ons nog sondaars was' (Rom 5:8). Daar is veral twee sake waarvoor elke gelowige hom- of haarself moet inspan, naamlik om hom los te maak van wat agter is en om uit te strek na wat voor is.

\section{'n Leier maak hom los van wat agter is}

Baie gelowiges meen dat hulle reeds geestelik volwasse is en die eindpunt van hulle geloofslewe en -groei bereik het; daarom gebruik Paulus die beeld van 'n atleet om die gelowiges in Filippi aan te moedig om na die regte gesindheid te streef (Hawthorne 2004). Wiersbe (1996) vat dit nog 'n stappie verder en sê dat Christene dikwels voel of hulle die eindpunt bereik het omdat hulle hul aan ander meet wat gewoonlik nie baie vordering maak nie. Melick (1991) wys daarop dat Paulus in teenstelling daarmee drie keer sy eie onvolmaaktheid soos volg beklemtoon: 'Ek sê nie dat ek dit alles al het nie ...' (3:12); '... ek verbeel my nie dat ek dit alles al het nie' (v. 13); 'Ons almal ... moet hierdie gesindheid hê' (v. 15).

Hierdie losmaak van wat agter is, hou volgens Müller (1992) alles in wat Paulus se aandag van sy doel kan aftrek (3:12) van die teleurstellings en aanvegtings (negatiewe), tot die oorwinnings (positiewe) wat kan lei tot selfverheffing of 'n houding dat jy reeds die doel bereik het.

\section{'n Leier strek hom uit na wat voor is}

Die enigste mikpunt moet wees om Christus te ontvang. Vroeër het Paulus hom met ander vergelyk (vgl. 3:3-6), maar ná sy ontmoeting met Christus weet hy dat God net met 
volmaaktheid tevrede is (Matt 5:48) en geen mens kan dit in hierdie lewe bereik nie. Jesus leer dus dat die een wat die hand aan die ploeg slaan en aanhou omkyk na wat agter is, nie vir die koninkryk geskik is nie (Luk 9:62). Die gelowige rig hom uitsluitlik op Christus en op wat hy in Hom ontvang.

Paulus se vertroue in die krag van Christus word verder in 3:15 beklemtoon as hy sy eie onvermoë bely om die gelowiges van die waarheid te oortuig. Hy weet dat alleen God 'n mens se oë kan verlig (vgl. Ef 1:18) om hierdie waarheid te verstaan (Hawthorne 2004).

Paulus se doelwitte as leier ná sy bekering kan soos volg saamgevat word:

- Paulus besef dat hy as kerkleier van Christus afhanklik is en daarom bely hy sy eie onvermoë om die gelowiges van hierdie waarheid te oortuig. In sy leierskap stel hy hom daarom onder Christus as sy hoof.

- Dit is opvallend dat Paulus dit baie duidelik stel dat die lewe van 'n gelowige nie maklik is nie, maar deur inspanning gekenmerk word. Paulus span hom met ywer in om Christus te leer ken wanneer hy besef wat Christus reeds vir hom gedoen het. Die status as kind van God dwing Paulus om sy lewe in verantwoordelikheid aan Christus toe te wy.

- Dat Paulus hom as leier losmaak van wat agter is, maak hom aan die een kant nie negatief oor terugslae of teleurstellings nie, maar aan die ander kant ook nie hoogmoedig oor al die positiewe dinge wat in sy lewe gebeur nie. Hy strek hom uit om Christus te ontvang en dit bring 'n nederige soeke na Christus se wil.

\section{Ordening van die leierseienskappe wat in 3:1-16 geopenbaar word}

Om die leierseienskappe wat in hierdie perikoop geopenbaar word te orden, sal die eienskappe wat met mekaar verband hou, saam gegroepeer word en vervolgens sal 'n oorkoepelende term vir beskrywing van elkeen van die groepe voorgestel word.

\section{Groep een}

Die volgende afleidings uit 3:1-16 oor Paulus se leierskap kan saamgegroepeer word:

- In die afdeling met die opskrif 'Paulus se doelwitte as leier ná sy bekering' (hierbo), is die beeld gebruik van seemanne wat in die middel van 'n storm besluit om alles oorboord te gooi om te verhoed dat hulle skipbreuk ly. Paulus het dieselfde gevoel oor die dinge wat hy vroeër as bate beskou het, maar na sy bekering verwerp het. Paulus het prakties gewys dat hy sy lewe onder Christus se heerskappy stel toe hy ter wille van Christus alles wat vir hom vroeër waardevol was, verwerp het. Hy het nie meer op homself nie, maar op Christus vertrou om hom te red. Die derde wens of doelwit (krag) sluit hierby aan. Paulus onderwerp hom aan Christus wat oneindige mag het en vertrou sy lewe aan
Hom toe eerder as om op sy eie beperkte krag staat te maak.

- Paulus is bewus van sy eie onvermoë om die gelowiges van die waarheid te oortuig dat hulle alles ter wille van Christus moet prysgee. Sy vertroue in Christus word duidelik in die belydenis dat God die gelowiges die regte insig sal gee en dat Hy alleen daartoe in staat is om 'n mens se oë te verlig (vgl. Ef 1:18).

Wat hierdie eienskappe met mekaar verbind, is dat Paulus hom volkome onder Christus stel en Hom vertrou as die Een wat in beheer van sy lewe en dié van ander is. Die oorkoepelende term vir hierdie groep eienskappe is onderdanige vertroue.

\section{Groep twee}

Verdere afleidings uit 3:1-16 oor Paulus se leierskap kan soos volg gegroepeer word:

- Ná Paulus se bekering ontvang hy'n nuwe status, naamlik Christen. Deur sy geloof word hy 'n ware nakomeling van Abraham (Gal 3:6-9). Onder die opskrif, 'Paulus se doelwitte as leier ná sy bekering' word daarop gewys dat hierdie nuwe status ook groter verantwoordelikheid tot gevolg het. Paulus sien die oppervlakkigheid van die Fariseërs se godsdiens en daarom aanvaar hy 'n hoër lewenspeil, naamlik om gelykvormig aan Christus te word (Rom 12:1-2). Die vryspraak en ewige heerlikheid (status) wat Christus aan Paulus gegee het, bring mee dat hy doelbewus sy hele lewe aan Christus wil wy. Hierdie verantwoordelikheid word verder onder die opskrif, 'Paulus se inspanning as leier van die kerk ná sy bekering' beklemtoon. Die woord wat Paulus gebruik en wat met 'ek span my in' vertaal is, herinner aan 'n wedloop waarin 'n atleet hom uitstrek na die wenstreep om eerste te wees. Net so het die gelowige ook 'n verantwoordelikheid om hom geestelik uit te strek na dít wat vir hom voorlê. Paulus gee die rede daarvoor in 3:12, naamlik '... omdat Christus Jesus my reeds syne gemaak het'. Omdat Paulus se status verander het, span hy hom in.

- Om hierdie status wat die gelowige in Christus ontvang met verantwoordelikheid te gebruik, moet hy teen hoogmoed waak. Onder die opskrif, 'Paulus se doelwitte as leier ná sy bekering' word daarop gewys dat Paulus nie geestelik hoogmoedig was nie, want hy het sy eie geestelike tekortkominge erken. Paulus wys telkens in hierdie gedeelte op sy eie tekortkominge $(3: 12,13,15)$. Voor Paulus se bekering sou hy hom maklik met ander kon vergelyk met betrekking tot al die goeie dinge wat hy gedoen het. Ná sy bekering weet hy egter dat hy niks kan doen om vryspraak te verdien nie. Hy vertrou alleen op dít wat Christus vir hom gedoen het en daarmee stel hy hom op dieselfde vlak as enige ander persoon. As leier maak Paulus hom ook los van wat agter is, wat beteken dat hy nie aan die een kant negatief raak oor terugslae of teleurstellings nie, maar aan die ander kant ook nie hoogmoedig raak oor al die positiewe dinge wat in sy lewe gebeur nie. 
Wat hierdie gedagtes met mekaar verbind, is dat Paulus se status verander het nadat hy tot geloof gekom het. Vroeër het hy sy status gesoek in dinge wat hy gedoen of vermag het, maar ná sy bekering soek hy sy status alleen in Christus en in dit wat Hy vir hom gedoen het. Deur op Christus se verlossingswerk te vertrou, word Paulus van alle hoogmoed gestroop en Christus word die inspirasie vir Paulus om sy lewe in verantwoordelikheid aan Hom alleen te wy. Hierdie groep eienskappe kan dus oorkoepelend as status met verantwoordelikheid beskryf word.

\section{Groep drie}

Die volgende afleidings uit 3:1-16 oor Paulus se leierskap kan saamgegroepeer word:

- Onder die opskrif, 'Die leierseienskap wat Paulus in sy reaksie teenoor die dwaalleraars toon' is daarop gewys dat gelowiges se gemoedere dikwels deur hulle omstandighede beïnvloed word. Omdat omstandighede voortdurend verander, is die gevolg daarvan dat dit een oomblik goed en die volgende sleg gaan. Ware blydskap word egter deur 'n verhouding met Christus bepaal en daardie blydskap bly konstant. Niks en niemand kan die blydskap wat 'n leier in Christus het van hom af wegneem nie. Die leier het egter wysheid nodig om te besef dat ware blydskap alleen in 'n verhouding met Christus te vinde is. In aansluiting by die vorige argument is daar ook onder die opskrif, 'Paulus se inspanning as leier van die kerk ná sy bekering' daarop gewys dat die gelowige op Christus moet vertrou. Niks wat die leier doen, kan hom of sy navolgers red nie. Dit is net Christus se werk om te red.

- Die teenoorgestelde opvatting word onder die opskrif, 'Paulus se begronding vir sy status as leier voor sy bekering' beskryf wanneer daar verwys word na Paulus wat in sy ywer vir die kerk 'n vervolger van die kerk van Christus geword het. Die rede daarvoor was dat hy nie op Christus vir sy verlossing vertrou het nie, maar op homself.

- Onder die opskrif 'Paulus se doelwitte as leier ná sy bekering' word na Paulus verwys wat sê dat dit sy enigste wens is om Christus te ken. Paulus se eerste wens of doelwit is kennis omdat hy die geestelike onderskeidingsvermoë ontvang het om sy fokus te verskuif deur veel eerder te soek na 'n innige verhouding met Christus, sy Verlosser. Net so sluit die vierde wens of doelwit (gemeenskap in sy lyding) ook hierby aan omdat Paulus iets begeer wat vir die wêreld onverklaarbaar is. Hy het besef dat hy selfs in sy lyding 'n metgesel het - Een wat deur baie groter lyding vir hom gegaan het en só sy krag is.

Wat in al hierdie sake beklemtoon word, is die insig en wysheid wat Paulus gehad het om nie vas te kyk teen die dinge wat volgens wêreldse standaarde goed, mooi en belangrik is nie. 'n Goeie leier het geestelike onderskeidingsvermoë nodig om te kan onderskei waarop dit werklik aankom. Daarom word hierdie groep eienskappe tuisgebring onder die term geestelike onderskeidingsvermö̈.

\section{Afgeleide beginsels vir elk van die eienskappe}

In hierdie afdeling word daar, ná 'n kort samevatting van elk van die eienskappe wat in die vorige afdeling genoem is, 'n aantal beginsels vir die spesifieke eienskap voorgestel.

\section{Onderdanige vertroue}

Die figurering van hierdie leierseienskap in die lewe van Paulus kan soos volg saam gevat word:

- Wat sy vryspraak betref, vertrou Paulus volkome dat Christus die vereiste prys vir hom betaal het. Niks wat hy doen, kan tot sy redding bydra nie.

- Hy onderwerp hom gewillig aan die wil van God ten opsigte van sy werk. Hy besef dat hy nie by magte is om mense van die waarheid te oortuig nie en daarom laat hy die oortuiging aan God oor.

Die onderdanige vertroue van die leier word volgens hierdie afleidings gebaseer op die volgende beginsels:

- Die leier moet besef dat hy alleen vryspraak ontvang deur 'n volkome vertroue in die verlossingswerk van Christus. Al die bagasie (tradisie, kultuur, taal, ens.) moet oorboord gegooi word indien dit in die pad na Christus staan.

- Onderdanige vertroue is verder ook nodig in die leier se werksomstandighede. Die leier moet besef dat dit net God is wat mense se harte ontvanklik kan maak om die waarheid te glo.

Enkele praktiese implikasies wat hierdie beginsels tot gevolg kan hê:

- Die fokus van die predikant verskuif. Waar hy vroeër daarop sou fokus om mense se harte te verander om die kerk te laat groei, word sy fokus verander om God in onderdanigheid te vertrou om op sy tyd die harte van mense te verander.

- Hierdie onderdanige vertroue skep dan ook verder 'n nederige gesindheid in die leier se hart wat byvoorbeeld daartoe sal lei dat hy nie sy oortuigings op ander afdwing asof dit die enigste waarheid is nie.

\section{Status met verantwoordelikheid}

Die figurering van hierdie leierseienskap in Paulus se lewe, kan soos volg saamgevat word:

- Deur Paulus se geloof in Christus ontvang hy die status as kind van God. Omdat hy besef watter genade daarmee gepaardgaan, leef hy vanuit die begeerte om sy hele lewe aan Christus te wy (vgl. 3:13-14). Hy neem hierdie verantwoordelikheid so ernstig op dat hy as leier aan sy navolgers opdrag gee om sy voorbeeld te volg soos hy die voorbeeld van Christus volg (1 Kor 4:16; 11:1).

- As leier wys Paulus deur sy lewe dat daar geen plek vir hoogmoed in 'n gelowige kan wees nie. Hy bely dat hy een van die grootste sondaars is (vgl. 1 Tim 1:15) en wys daarmee dat hy selfs as apostel geensins beter is as enige 
ander gelowige wat sy verlossing in Christus vind nie. Daarom roem Paulus alleen op Christus en op niks wat hy doen nie.

Die leier se status met verantwoordelikheid word volgens hierdie afleidings op die volgende beginsels gebaseer:

- Die leier moet bewus wees van die nuwe status wat hy in Christus ontvang. Die gelowige leier is nie meer 'n slaaf van die sonde nie, maar in Christus 'n kind van God. As kind van God kry hy ook 'n groot verantwoordelikheid, want sy lewe moet van kindskap getuig. Uit dankbaarheid moet die leier sy hele lewe aan God wy as 'n lewende en heilige offer.

- Status met verantwoordelikheid mag nooit daartoe lei dat die leier hoogmoedig raak nie. Hoogmoed getuig daarvan dat die leier nie besef dat hy soos enige ander persoon skuldig voor God oor sy sonde staan nie. In Christus word almal gelyk voor God.

Enkele praktiese implikasies wat hierdie beginsels tot gevolg kan hê:

- Die feit dat die leier besef dat hy soos enige ander persoon skuldig voor God staan, sal tot gevolg hê dat die leier homself nie hoër as ander mense ag nie. Hy sal daarom nie sy status probeer vind in sy amp nie, maar eerder in die genade wat alleen in Christus is.

- Die gevolg van hierdie nuwe status in Christus sal wees dat die leier verantwoordelikheid vir die regte sake neem. Hy sal byvoorbeeld nie na sy eie eer soek nie, maar na die eer van Christus. Hy sal ook nie gefokus wees op sy eie wil wat moet geskied nie, maar hy sal biddend vra na die wil van God.

\section{Geestelike onderskeidingsvermoë}

Op grond van Paulus se leierskap wat in 3:1-16 geopenbaar word, kan afgelei word dat die leierskapbegrip geestelike onderskeidingsvermoë soos volg in Paulus se leierskap figureer:

- Paulus se geestelike onderskeidingsvermoë word sigbaar in sy hantering van sy omstandighede. Sy blydskap word nie deur sy omstandighede bepaal nie, maar hy besef dat selfs ook die slegte omstandighede in diens van God se koninkryk staan.

- In Paulus se lewe ná sy bekering is dit duidelik dat hy die geestelike onderskeidingsvermoë het om in te sien dat hy in Christus alleen gered kan word. Die gevolg van hierdie insig is die begeerte na ' $n$ diep en innige verhouding met Christus.

Uit die realisering van die leierskapsbegrip geestelike onderskeidingsvermoë in Paulus se leierskap word die volgende beginsels vir die leierskap van die predikant afgelei:

- Dieleiermoetdienodigegeestelikeonderskeidingsvermoë hê om in te sien dat sy en ook die gemeente se blydskap nie deur hulle omstandighede bepaal word nie, maar deur hulle verhouding met Christus. As Christus 'n persoon se blydskap bepaal, sal hy in alle omstandighede bly kan wees, want niks kan hom van die liefde van Christus skei nie (vgl. Rom 8:38-39).

- 'n Leier met geestelike onderskeidingsvermoë besef ook dat daar niks is wat hy kan doen om gered te word nie. Christus het alles vir hom en in sy plek gedoen. Wanneer die leier hierdie waarheid besef, sal hy begeer om 'n diep en innige verhouding met Christus te hê. Daarom moet die leier ook die gemeente uitsluitlik op Christus rig en op wat hulle in Hom ontvang.

Enkele praktiese implikasies wat hierdie beginsels tot gevolg kan hê:

- Die leier met geestelike onderskeiding soek sy blydskap in Christus. Hy lei die gemeente daarin om in te sien dat teleurstellings en aanvegtings hulle nie van daardie blydskap in Christus mag beroof nie. As leier moet hy die gemeente eerder meer op Christus rig en op wat hulle in Hom ontvang het.

- Net soos Paulus sal die leier met geestelike onderskeiding die innerlike vrede (vgl. 1:18-19) hê omdat hy daarvan oortuig is dat Christus sy gemeente lei - selfs ook daar waar hy as leier tekortskiet.

\section{Beginsels vir effektiewe en verantwoordelike leierskap soos afgelei uit 3:1-16}

In hierdie artikel is aangetoon hoe verskillende leierskapsbegrippe volgens 3:1-16 in die leierskap van Paulus gefigureer het. Onder elkeen van hierdie leierskapsbegrippe is beginsels vir die leierskap van die predikant geformuleer. Hierna word aangedui hoe die kerkleier hierdie beginsels prakties in sy leierskap kan toepas.

Praktiese toepassing van onderdanige vertroue: Die leier moet God onderdanig vertrou vir sy verlossing, sukses in sy werk, die omstandighede waarin hy sy werk doen en vir wat die toekoms vir hom sal inhou. Hy moet dus sy hele lewe deur in onderdanige vertroue op God leef.

Praktiese toepassing van status met verantwoordelikheid: Deur die genade wat hy in Christus ontvang, ontvang die leier ook nuwe status, naamlik kind van God. Die verantwoordelikheid wat met hierdie status gepaardgaan, is dat die leier sy kindskap moet bewys deur sy lewe in dankbaarheid aan sy Vader te wy.

Praktiese toepassing van geestelike onderskeidingsvermoë: Die leier moet besef dat geestelike onderskeidingsvermoë nodig is om in te sien dat sy omstandighede nie sy geluk en sukses bepaal nie. Net ' $n$ innige verhouding met Christus kan ware blydskap verskaf.

\section{Erkenning Mededingende belange}

Die outeur verklaar dat hy geen finansiële of persoonlike verbintenis het met enige party wat hom nadelig kon beïnloed het in die skryf van hierdie artikel nie. 


\section{Outeurs bydrae}

P.B. was die outeur van die manuskrip en B.d.K. was die studieleier wat hom gehelp het om die artikel te skryf.

\section{Literatuurverwysings}

Calvyn, J. \& Pringle, J., 2010, Commentaries on the Epistles of Paul, the Apostle, to the Philippians, Colossians, and Thessalonians, Bellingham, WA.

Carson, D.A., France, R.T., Motyer, J.A. \& Wenham, G.J., 1994, New Bible commentary: 21st century edition, 4th edn., InterVarsity Press, Leicester.

De Klerk, B.J. \& Janse van Rensburg, J.J., 2005, Preekgeboorte: 'n handleiding vir Gereformeerde eksegese en prediking toegepas op 1 Petrus 2:11-12, 18-25, Potchefstroomse Teologiese Publikasies, Potchefstroom.

Hawthorne, G.F., 2004, Philippians, Word Incorporated, Dallas, TX. (Word Biblical commentary, 43).

Henry, M., 1994, Matthew Henry's commentary on the whole Bible: Complete and unabridged in one volume, Hendrickson, Peabody, MA.

Keener, C.S., 1993, The IVP Bible background commentary: New Testament, InterVarsity Press, Downers Grove, IL.

Lotter, G.A., 1993, Die werk van die Heilige Gees in die gelowiges volgens 2 Korintiërs, ThD-proefskrif, PU vir $\mathrm{CHO}$, Potchefstroom.
Louw, J.P. \& Nida, E.A., 1996, A Greek-English lexicon of the New Testament: Based on semantic domains, vol. 1., United Bible Societies, New York, NY.

MacArthur, J.F., Jr., 2001, Philippians, MacArthur New Testament commentary, Moody Press, Chicago, IL.

MacArthur, J.F., Jr. (ed.), 2006, John 1-11, MacArthur New Testament commentary, Moody Press, Chicago, IL.

Melick, R.R., 1991, Philippians, Colossians, Philemon, The new American commentary Broadman \& Holman, Nashville, TN. (The New American Commentary, 32).

Müller, J.J., 1992, Die brief aan die Filippense, die brief aan Filemon, NG Kerk Uitgewers, Kaapstad.

Rardin, R., 1998, Servant Shepherd Ministries, viewed 1 May 2011, from http://www. servantshepherd.com/Introductions.htm

Robertson, A., 1933, Word pictures in the New Testament, Broadman Press, Nashville, TN.

Van Zyl, A.H., 1993, Die Bybel verklaar: 1983-vertaling, Lux Verbi, Kaapstad.

Vincent, M.R., 1887, Word studies in the New Testament, Charles Scribner's Sons, New York, NY.

Vosloo, W. \& Van Rensburg, F.J., 1993, Die Bybel in praktyk: Nuwe vertaling, Christelike Uitgewersmaatskappy, Vereeniging.

Vosloo, W. \& Van Rensburg, F.J., 1999, Die Bybellennium eenvolumekommentaar: Die Bybel uitgelê vir eietydse toepassing, Christelike Uitgewersmaatskappy, Vereeniging.

Wiersbe, W.W., 1992, Wiersbe's expository outlines on the New Testament, Victor Books, Wheaton, IL.

Wiersbe, W.W., 1996, The Bible exposition commentary, Victor Books, Wheaton, IL. 